\title{
Divergent symbiont communities determine the physiology and nutrition of a reef coral across a light-availability gradient
}

\author{
Christopher B. Wall $\mathbb{D}^{1,2} \cdot$ Mario Kaluhiokalani $^{1} \cdot$ Brian N. Popp $\mathbb{1}^{3} \cdot$ Megan J. Donahue $^{1} \cdot$ Ruth D. Gates ${ }^{1}$
}

Received: 22 July 2019 / Revised: 25 November 2019 / Accepted: 11 December 2019 / Published online: 3 January 2020

(c) The Author(s) 2020. This article is published with open access

\begin{abstract}
Reef corals are mixotrophic organisms relying on symbiont-derived photoautotrophy and water column heterotrophy. Coral endosymbionts (Family: Symbiodiniaceae), while typically considered mutualists, display a range of species-specific and environmentally mediated opportunism in their interactions with coral hosts, potentially requiring corals to rely more on heterotrophy to avoid declines in performance. To test the influence of symbiont communities on coral physiology (tissue biomass, symbiont density, photopigmentation) and nutrition $\left(\delta^{13} \mathrm{C}, \delta^{15} \mathrm{~N}\right)$, we sampled Montipora capitata colonies dominated by a specialist symbiont Cladocopium spp. or a putative opportunist Durusdinium glynnii (hereafter, C- or D-colonies) from Kāne'ohe Bay, Hawai' $i$, across gradients in photosynthetically active radiation (PAR) during summer and winter. We report for the first time that isotope values of reef corals are influenced by Symbiodiniaceae communities, indicative of different autotrophic capacities among symbiont species. D-colonies had on average $56 \%$ higher symbiont densities, but lower photopigments per symbiont cell and consistently lower $\delta^{13} \mathrm{C}$ values in host and symbiont tissues; this pattern in isotope values is consistent with lower symbiont carbon assimilation and translocation to the host. Neither C- nor D-colonies showed signs of greater heterotrophy or nutritional plasticity; instead changes in $\delta^{13} \mathrm{C}$ values were driven by PAR availability and photoacclimation attributes that differed between symbiont communities. Together, these results reveal Symbiodiniaceae functional diversity produces distinct holobionts with different capacities for autotrophic nutrition, and energy tradeoffs from associating with opportunist symbionts are not met with increased heterotrophy.
\end{abstract}

\section{Introduction}

Nutrient exchanges between scleractinian corals and dinoflagellate symbionts (Symbiodiniaceae, formerly Symbiodinium spp.) [1] underpin the success of reef-building corals as habitat engineers in coral reef ecosystems [2]. Reef corals are mixotrophic, reliant on the translocation of

Supplementary information The online version of this article (https:// doi.org/10.1038/s41396-019-0570-1) contains supplementary material, which is available to authorized users.

Christopher B. Wall

cbwall@hawaii.edu

1 Hawai'i Institute of Marine Biology, University of Hawai'i at Mānoa, PO Box 1346, Kāne'ohe, HI 96744, USA

2 Pacific Biosciences Research Center, University of Hawai ' $i$ at Mānoa, 1993 East-West Road, Honolulu, HI 96822, USA

3 Department of Earth Sciences, University of Hawai'i at Mānoa, 1680 East-West Rd, POST 701, Honolulu, HI 96822, USA symbiont-derived compounds [3, 4] and heterotrophy in support of respiratory demands, calcification, and tissue growth [5-7]. In exchange, Symbiodiniaceae receive metabolic byproducts (i.e., $\mathrm{CO}_{2}, \mathrm{NH}_{4}{ }^{+}$) required for growth and photosynthesis [8]. However, reef corals are increasingly threatened by climate change and local stressors, which disrupt the coral-algae symbiosis and reduce ecosystem services provided by coral reefs $[9,10]$. Associations with stress-tolerant symbionts can provide increased stress tolerance for corals albeit at the expense of coral performance [11], potentially requiring greater heterotrophic feeding to meet energy demands.

The genetic and functional diversity of Symbiodiniaceae shapes the energy balance and stress tolerance of reef corals. Taxonomic resolution of Symbiodiniaceae has been achieved using genetic markers, primarily the internal transcribed spacer 2 (ITS2) region of nrDNA [12, 13], and has revealed distinct symbiont genera and species (formerly clades and subclades) [1] with different capacities to support coral nutrition [14, 15] and tolerate environmental stress [16]. For instance, symbionts in the genus 
Symbiodinium (formerly clade A) and Durusdinium (formerly clade D) are common on shallow reef zones of the Red Sea and Caribbean [17, 18] and are also tolerant of high light and temperature stress. In particular, Durusdinium is observed in higher abundance on reefs impacted by local stressors or a history of bleaching [16, 19-21]. However, some members of Symbiodinium and Durusdinium have been identified as opportunistic generalist symbionts, assimilating and transferring less carbon and nitrogen compounds to their coral hosts compared to specialist symbionts with high host specificity, such as members of Cladocopium and Breviolum genera (formerly clade $\mathrm{C}$ and $\mathrm{B}$, respectively) $[14,15,17,22,23]$. As a consequence, corals in association with stress-tolerant symbiont species may be less sensitive to environmental change but incur energetic tradeoffs [24], including reduced autotrophic nutrition, lower tissue, and skeletal growth rates, and attenuated reproductive output compared to more mutualistic symbionts (i.e., Cladocopium and Breviolum) [11, 25-29]. To cope with reductions in symbiont-derived nutrition from less-mutualistic symbionts, it has been hypothesized that coral hosts may shift towards greater heterotrophy to meet metabolic demands [30,31], as has been observed in corals under experimental thermal stress ([32], but see in situ [33]) and on high turbidity reefs [34]. However, intraspecific changes in symbiont communities also reflect Symbiodiniaceae niche specialization, with some species being more efficient in uptake of carbon or nitrogen under low or high light and/or temperatures [17, 23]. Therefore, it is important to unravel the ecological contexts and effects of symbiont communities on coral nutrition to determine the capacity for corals to be nutritionally plastic or to cope with opportunistic symbiont effects on performance [17, 30].

Environmental factors, such as light availability [35-37], water quality [38], temperature [39], and bleaching history $[40,41]$ are important in shaping the composition of symbiont communities. Changes in photosynthetically active radiation (PAR, hereafter 'light') influence the ecological niche of reef corals [42], and many coral species exhibit shallow-to-deep transitions in symbionts in favor of those adapted to lower light levels. For example, shallow colonies of Seriatopora hystrix in Western Australia [43] are dominated by Durusdinium, whereas deeper colonies are more often dominated by Cladocopium symbionts. Similarly, shallow-to-deep transitions from Symbiodinium (shallow) to Cladocopium (deep) have been observed in Stylophora pistillata [17] in the Red Sea and Orbicella faveolata in the Caribbean [18]. Where depth and turbidity attenuate light, corals can rely on the photoacclimation potential of their endosymbionts [43] and/or heterotrophy to prevent energy deficits [34, 44].

Carbon and nitrogen stable isotope analyses of tissues have been applied to understand the balance of autotrophy and heterotrophy in reef corals and anemone model systems. These studies are widely interpreted as evidence for greater relative contributions of heterotrophy relative to autotrophy in corals during periods of resource limitation (i.e., reduced light availability) [45] or symbiosis disruption (i.e., coral bleaching) [46] and in regions characterized by high primary production [47]. However, the capacity for nutritional plasticity is not shared by all corals and depends on the biology of the coral host [48] and the optimization of skeletal morphology for light absorption or prey capture [49]. Recent research using corals and cnidarian model systems has also shown that the capacity for corals to increase heterotrophic feeding is also determined by Symbiodiniaceae communities [17, 30]. For instance, Cladocopium-associated Stylophora pistillata corals exhibited greater feeding rates but lower inorganic nitrogen assimilation rates than shallow Symbiodinium-associated colonies [17]. Similarly, Durusdinium-associated anemones did not shift towards greater prey capture when carbon translocation was low and exhibited lower feeding and digestion rates compared to anemones with Symbiodinium minutum symbionts [30]. These studies have shown symbiont community composition can influence the trophic ecology of corals and anemones with downstream implications for host performance. Due to uncertain boundaries in symbiont community distributions, few inquiries have examined the role of symbiont type on corals across natural environmental gradients (but see refs. [35, 43]) or symbiont-driven effects on coral feeding rates and the balance between autotrophic and heterotrophic nutrition. Yet, such inquires are necessary to understand the metabolic tradeoffs from distinct host-symbiont associations and symbiont effects on coral energy budgets.

Here, we examine changes in the physiology and heterotrophic capacity (carbon and nitrogen stable isotope analyses) of a Hawaiian reef coral (Montipora capitata) dominated by algal symbionts Durusdinium glynnii (ITS2: D1-4-6 [50]) or Cladocopium spp. (ITS2: dominated by C31 [51], but see ref. [52]) from $<1-10 \mathrm{~m}$ during summer and winter. M. capitata shows depth-dependent shifts in symbiont communities (greater Durusdinium sp. at shallow depths [36]) and can exhibit stress-induced changes in nutritional modes [32]. Therefore, we predicted greater heterotrophic feeding in $M$. capitata under significant light attenuation [45, 47] and during association with opportunistic generalist symbionts (i.e., Durusdinium). We observed greater symbiont densities and lower carbon isotopic values indicative of lower rates of carbon fixation and autotrophy in corals associating with Durusdinium, but neither Cladocopium- nor Durusdinium-dominated colonies exhibited greater heterotrophic feeding across light gradients or seasons. Isotope values in corals across depth gradients have been previously explored ([47, 49]); 
however, our study offers the first evidence of symbiont community effects on host isotope values along a light gradient, where isotope values serve as proxies for coral productivity and nutritional modes. These findings reveal distinct traits of coral holobionts (symbiont and photopigment concentrations, carbon isotope values) that are determined by interactions between symbiont communities and environmental drivers, but do not lead to shifts toward greater heterotrophic nutrition.

\section{Materials and methods}

\section{Site information}

Montipora capitata [53] colonies were sampled from four reefs spanning Kāne'ohe Bay on the windward side of O'ahu, Hawai'i, USA (Fig. 1). Inshore Kāne'ohe Bay is shallow $(<15 \mathrm{~m})$, and below $\sim 6 \mathrm{~m}$ coral colonies are rare as fine silt dominates the benthos [54]. Sampling periods were defined as "summer" and "winter", corresponding to historical periods of low and high seasonal rainfall [55]. Summer samples were collected in 2016 (June 8, July 11 and 29, August 3 and 9) [36], and winter samples were collected on December 19, 2016. Maximum seawater temperatures in 2016 for southern Kāne 'ohe Bay did not exceed historical averages $\left(\leq 29^{\circ} \mathrm{C},[55]\right)$ and bleaching was not observed.

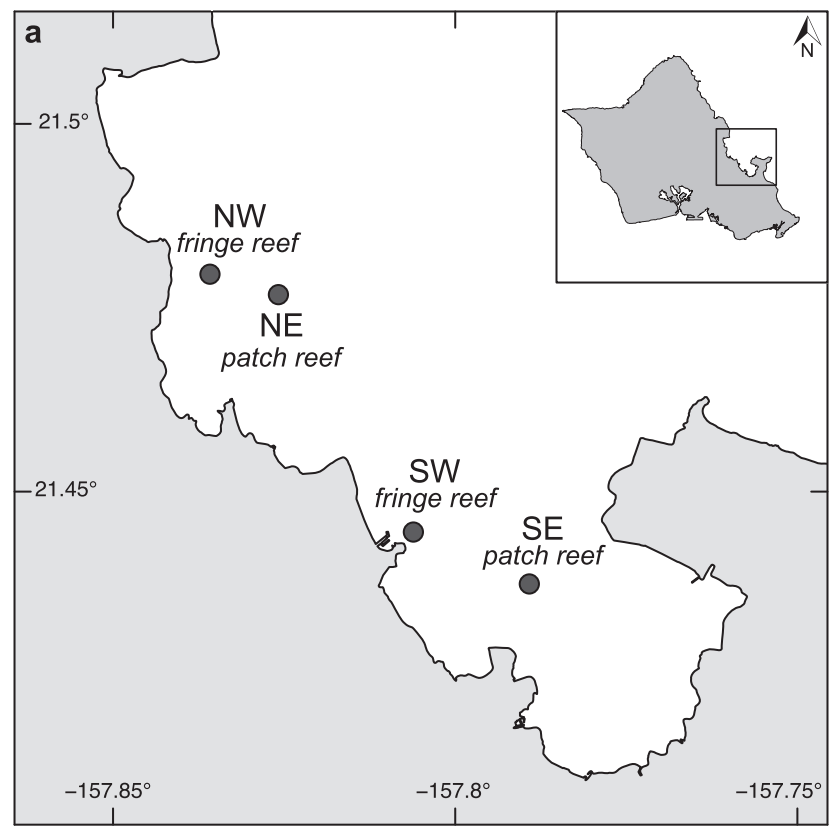

Fig. 1 Site map and the coral Montipora capitata. a Map of Kāne'ohe Bay on the windward side of $\mathrm{O}$ 'ahu, Hawai' $\mathrm{i}$ and $\mathbf{b}$ the coral Montipora capitata. Circles represent locations where corals were collected. Northern Kāne'ohe Bay locations were a fringe reef ('Northwest' [NW]: $21^{\circ} 28^{\prime} 46.5^{\prime \prime} \mathrm{N}, 157^{\circ} 50^{\prime} 08.7^{\prime \prime W}$ ) and a patch reef

\section{Environmental conditions}

Light environments across the four locations were described using cross-calibrated PAR light loggers (Odyssey, Dataflow Systems Limited, Christchurch, New Zealand) deployed at the four collection locations at $2 \mathrm{~m}$-depth from 10 June 2016-11 January 2017 recording every $15 \mathrm{~min}$ and cleaned monthly. Integrated light-at-depth values for coral colonies was determined using light loggers at three depths (<1 m, 2 m, $8 \mathrm{~m})$ 9-17 October 2016 and 9-19 November 2016 and calculating location-specific light attenuation coefficients $\left(\mathrm{kd}_{\mathrm{x}}\right)$ and daily light integrals (DLI), using a modified Beer-Lambert equation for light attenuation (see Supplemental Materials). Seawater temperatures were recorded at each site at 2 m-depth from June 2016 to January 2017 using cross-calibrated loggers (Hobo Pendant loggers $\pm 0.53{ }^{\circ} \mathrm{C}$ accuracy, Onset Computer Corp., Bourne, USA) recording at $15 \mathrm{~min}$ intervals.

Seawater dissolved nutrients and the isotope values of plankton (i.e., isotope end-members) were sampled 10 August and 19 December 2016 and used to account for site and seasonal differences in biogeochemistry. Seawater was collected at each location, filtered to remove plankton and debris (GF/F filters $0.7 \mu \mathrm{m}$ nominal pore size), and frozen $\left(-20^{\circ} \mathrm{C}\right)$ in acid-washed $(0.1 \mathrm{~N} \mathrm{HCl})$ HDPE bottles until analysis (see Supplemental Materials). Plankton/suspended particles were collected with vertical $(<10 \mathrm{~m})$ and horizontal plankton tows $(63 \mu \mathrm{m}$ mesh) and seawater $(10 \mathrm{~L})$ collected

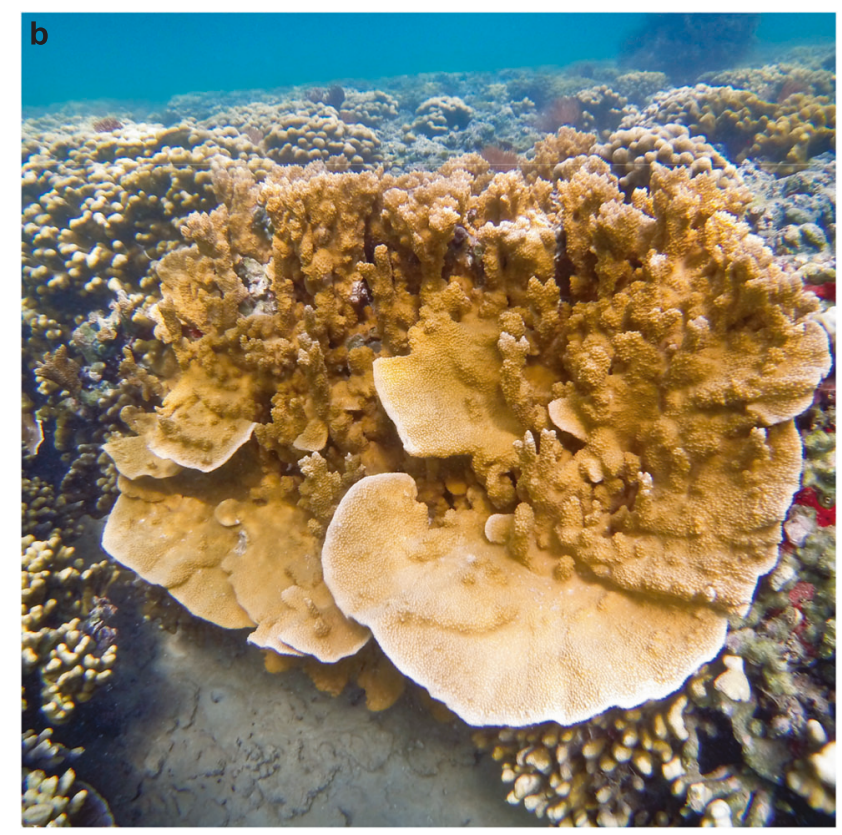

('Northeast' [NE]: $21^{\circ} 28^{\prime} 36.5^{\prime \prime} \mathrm{N}, 157^{\circ} 49^{\prime} 33.1^{\prime \prime W}$ ); southern locations were a fringe reef (near He'eia loko i'a [fishpond)]) ('Southwest' [SW]: $21^{\circ} 26^{\prime} 40.3^{\prime \prime} \mathrm{N}, 157^{\circ} 48^{\prime} 21.6 " \mathrm{~W}$ ) and the reefs of Moku o Lo'e at the Hawai'i Institute of Marine Biology ('Southeast' [SE]: $21^{\circ}$ 26'14.9"N, 157²7'21.3"W). (Photo credit: CB Wall). 
at 3 m-depth. Particles were size fractioned $(<10,10-100$, $100-243 \mu \mathrm{m}$, and separate pooled samples of all particles $<243$ and $>243 \mu \mathrm{m})$, filtered onto GF/F filters $(0.7 \mu \mathrm{m})$, and dried $\left(60^{\circ} \mathrm{C}\right)$ until isotope analyses (detailed below).

\section{Coral sampling and tissue analysis}

At each of the four reefs in summer and winter, branch tips $\left(4 \mathrm{~cm}^{2}\right)$ were collected from five $M$. capitata colonies at each reef location within three depth strata $(0-2 \mathrm{~m}, 2-5 \mathrm{~m}$, 5-10 m) spanning the depth gradient where colonies were observed ( $n=15$ samples per location). Colony depth and time of collection was noted to correct for tidal height, with final depths corrected to mean seawater height using NOAA tide data at 6-min intervals for Moku o Lo'e (Station ID: 1612480) from CO-OPS API in a custom $R$ code [36]. Immediately after collection, corals were flash-frozen in liquid nitrogen, transported to $\mathrm{HIMB}$, and stored at $-80{ }^{\circ} \mathrm{C}$.

Coral tissues were removed from the skeleton using an airbrush with filtered seawater $(0.7 \mu \mathrm{m})$. The tissue slurry was homogenized and aliquots taken for physiology and isotopic analysis. Symbiont cell densities were determined by microscopy ( $n=4-8$ counts) using a haemocytometer. Photopigments (chlorophyll $a$ and $c_{2}$ ) were extracted in $100 \%$ acetone and measured by spectrophotometry [56] (see Supplemental Materials). Ash-free dry weight (AFDW) (i.e., total host + symbiont biomass) of holobiont tissues was quantified as the difference between dried $\left(60{ }^{\circ} \mathrm{C}, 24 \mathrm{~h}\right)$ and combusted masses $\left(450{ }^{\circ} \mathrm{C}, 4 \mathrm{~h}\right)$. All physiological metrics (cell densities, chlorophyll concentrations, total biomass) were standardized to coral surface area, determined using the wax-dipping technique [57]; chlorophylls were additionally normalized to symbiont cell abundance [58].

\section{Stable isotope analysis}

Stable isotope analyses were performed on suspended particles and plankton from filtered seawater (detailed above), separated coral and symbiont tissues, and coral skeleton material to examine the trophic ecology and nutrient exchanges between host and symbiont. Samples were not acidified [59] or bleached [60] prior to isotope analysis. Coral and symbiont tissues were separated by centrifugation with filtered seawater rinses [45] and filtered to remove skeletal debris and avoid the contribution of carbonates on isotope values [61]. The effectiveness of filtration was confirmed by regressing sample $\mathrm{C}: \mathrm{N}$ against $\delta^{13} \mathrm{C}$ values (see Supplemental Materials). Carbon $\left(\delta^{13} \mathrm{C}\right)$ and nitrogen $\left(\delta^{15} \mathrm{~N}\right)$ and tissue molar $\mathrm{C}: \mathrm{N}$ ratio for coral host $\left(\delta^{13} \mathrm{C}_{\mathrm{H}}\right.$, $\left.\delta^{15} \mathrm{~N}_{\mathrm{H}}, \mathrm{C}: \mathrm{N}_{\mathrm{H}}\right)$ and algal symbiont $\left(\delta^{13} \mathrm{C}_{\mathrm{S}}, \delta^{15} \mathrm{~N}_{\mathrm{S}}, \mathrm{C}: \mathrm{N}_{\mathrm{S}}\right)$ tissues were determined using elemental combustionisotope ratio mass spectrometry (IRMS) with glycine standards characterized by international reference materials and in-house standards of tuna white muscle tissue, with $<0.2 \%$ sample analytical precision and accuracy (see Supplemental Materials). The relative differences of host and symbiont carbon $\left(\delta^{13} \mathrm{C}_{\mathrm{H}-\mathrm{S}}\right)$ and nitrogen $\left(\delta^{15} \mathrm{~N}_{\mathrm{H}-\mathrm{S}}\right)$ isotope values were calculated as metrics for heterotrophic capacity (i.e., $\delta^{13} \mathrm{C}_{\mathrm{H}-\mathrm{S}}$ ) and changes in trophic enrichment (i.e., $\delta^{15} \mathrm{~N}_{\mathrm{H}-\mathrm{S}}$ ) [46, 62].

Skeletal carbon $\left(\delta^{13} \mathrm{C}_{\mathrm{Sk}}\right)$ and oxygen $\left(\delta^{18} \mathrm{O}\right)$ isotope values in the uppermost layers of the coral skeleton (ca.1-2 mm, ca. $80 \mu \mathrm{g}$ ) were measured by acidifying skeletal material (100\% orthophosphoric acid) under vacuum $\left(90^{\circ} \mathrm{C}\right)$ and measuring released $\mathrm{CO}_{2}$ by IRMS; reference material (marble $\mathrm{CaCO}_{3}$ standard) deviated by $0.02 \%$ o $\left(\delta^{18} \mathrm{O}\right)$ and $<0.2 \%$ o $\left(\delta^{13} \mathrm{C}\right)$. Kinetic isotope effects (KIE) on skeletal carbonates were investigated using estimates for carbon and oxygen isotope equilibrium $\left(\delta^{13} \mathrm{C}_{\mathrm{eq}}\right.$ and $\delta^{18} \mathrm{O}_{\mathrm{eq}}$, respectively) for skeletal aragonite, estimated using values from Schoepf et al. [63] (see Supplemental Materials). Stable isotope ratios are reported using delta values $(\delta)$ in permil $(\%)$ notation relative to Vienna Pee-Dee Belemnite (V-PBD) $\left(\delta^{13} \mathrm{C}, \delta^{18} \mathrm{O}\right)$ and atmospheric $\mathrm{N}_{2}$ (air) $\left(\delta^{15} \mathrm{~N}\right)$.

\section{DNA extraction and symbiont community analysis}

Numerous reports have shown M. capitata Symbiodiniaceae communities in Hawai' $i$ to be comprised only of Cladocopium and Durusdinium, with Durusdinium found only in Kāne'ohe Bay [20, 51]. We quantified Symbiodiniaceae communities by extracting symbiont DNA (following [51]) and using qPCR targeting actin gene loci for Cladocopium [51] and Durusdinium [50]. The relative abundance of Cladocopium and/or Durusdinium was determined for each colony using two replicate qPCR reactions, with normalization applied for reporter dye fluorescence intensity with estimates of DNA extraction efficiency and actin gene copy number for each symbiont species (detailed in, [64]). Each colony was categorized as either Cladocopium- or Durusdinium-dominated (i.e., $\mathrm{C}$ - and D-colonies) based on the numerical abundance of these two genera (threshold: proportion >0.5) [36] (for further information see Supplemental Materials).

\section{Statistical analysis}

Differences in daily light integral were analyzed in a linear mixed effect model with location and season as fixed effects and date-of-collection as a random effect. Other environmental data (dissolved nutrients, plankton) were analyzed in a linear model with reef locations and seasons as fixed effects. The dominant Symbiodiniaceae species in $M$. capitata (i.e., categorical with symbiont dominance $[\mathrm{C}$ or $\mathrm{D}]$ as $\mathrm{qPCR}>0.5$ proportion) was analyzed using a logistic 
model with a binomial distribution; colony depth, season, and location were treated as main effects [36]. Models were tested using AIC model selection [65] and likelihood ratio tests of main effects. Tests of the relationship between response metrics, spatiotemporal factors (i.e., season, location, colony depth-bins), and symbiont community were performed using a principal components analyses (PCA) of a scaled and centered correlation matrix; PERMANOVA tests of main effects were evaluated in the package vegan [66]. Biological response variables (total biomass, symbiont densities, areal and symbiont cell-specific chlorophyll concentrations) were analyzed in a linear mixed effect model (lme4 [67]) with season (winter vs. summer), light-at-depth (continuous variable), and dominant symbiont community (Cladocopium vs. Durusdinium) as fixed categorical effects and location as a random effect; final models were selected according to AIC. Pairwise post-hoc slice-tests of main effects were performed using estimated marginal means (emmeans [68]). Analysis of variance tables were generated using car [69] and mixed-effect lmerTest packages [70]. Subsequently to testing main effects on response variables, linear regressions were used to evaluate the influence of symbiont traits (cell density, total areal chlorophyll, chlorophyll symbiont cell $^{-1}$ ) on $\delta^{13} \mathrm{C}$ values in the host and symbiont in each season. All statistical analyses were performed in R version 3.5.2 [71]. Data and scripts to reproduce analyses and figures are archived at Zenodo [72] and available at Github.

\section{Results}

\section{Environmental conditions}

Light availability, expressed as the daily light integral (i.e., DLI), was higher in summer relative to winter $(p<0.001)$ and similar across all locations except for lower DLI at the southwest location $(p<0.001)$ (Table S1, Fig. S1a). Estimates for DLI from June 2016 to January 2017 (mean \pm SE, $n=163-198)$ at $<1 \mathrm{~m}$ were $17.3-21.3 \pm 0.6 \mathrm{~mol}$ photons $\mathrm{m}^{-2} \mathrm{~d}^{-1}$ at all locations, except the southwest location $\left(9.8 \pm 0.5\right.$ mol photons $\left.\mathrm{m}^{-2} \mathrm{~d}^{-1}\right)$ (Fig. S2). Relative to $<1 \mathrm{~m}$, DLI was attenuated by 61 and $82 \%$ at $2 \mathrm{~m}$ and $8 \mathrm{~m}$-depths, respectively. Seasonally averaged DLI from loggers at $2 \mathrm{~m}$ were $9.3-15.6 \mathrm{~mol}$ photons $\mathrm{m}^{-2} \mathrm{~d}^{-1}$ (summer) and 2.8-8.4 mol photons $\mathrm{m}^{-2} \mathrm{~d}^{-1}$ (winter). Daily mean seawater temperatures were similar across all sites, with summer maximum temperatures ranging from 27 to $29{ }^{\circ} \mathrm{C}$; winter temperatures ranged from 24 to $25^{\circ} \mathrm{C}$ (Fig. S1b). Nutrient concentrations remained low and changes among sites and seasons were small (Fig. S3). Phosphate, ammonium, and nitrate + nitrite $(\mathrm{N}+\mathrm{N})$ concentrations were higher in winter compared to summer $(p \leq 0.046)$ (Table S1), and the two northern sites had higher $\mathrm{N}+\mathrm{N}$ (summer and winter) and phosphate (winter only) concentrations compared to southern sites $(p<0.001)$.

Carbon and nitrogen isotope values of suspended particles and plankton did not differ between locations $(p \geq$ 0.146 ) and seasonal effects on $\delta^{15} \mathrm{~N}$ values were small $(0.3 \%$ difference) $(p \geq 0.049)$ (Table S1). The mass of organic fractions (i.e., AFDW) represented in suspended materials $(0.7$ to $<243 \mu \mathrm{m})$ were also found to be similar across sites and seasons at ca. $1-2 \mathrm{mg} \mathrm{L}^{-1}$ (data not shown). Therefore, isotope values were pooled among the locations and seasons to generate isotope end member plots (Fig. S4). Mean $\delta^{13} \mathrm{C}$ values were similar for all size fractions across seasons and locations $\left(-18.1\right.$ to $-21.1 \%$ ). Mean $\delta^{15} \mathrm{~N}$ values were lowest in $<10 \mu \mathrm{m}(5.3 \%$ ) , intermediate in $100-243 \mu \mathrm{m}(6.5 \%)$, and highest in $10-100 \mu \mathrm{m}$ fractions (7.4\%o). In pooled samples, small particles $(0.7$ to $<243 \mu \mathrm{m})$ were ca. $1 \%$ depleted in ${ }^{15} \mathrm{~N}$ relative to large particles $(>243 \mu \mathrm{m})(5.9$ and $6.8 \%$, respectively).

\section{Symbiont community}

Corals were collected over comparable depth ranges in summer (0.2-9.4 m) and winter (0.2-7.7 m) (Fig. S5). The distribution of dominant Symbiodiniaceae was depthdependent in both seasons $(p<0.001)$ and did not differ among locations $(p=0.339)$. Importantly, because colonies were randomly sampled in each season (i.e., individuals were not tagged and resampled), these data cannot be used to evaluate symbiont shuffling across time, but instead reflect ecological patterns of holobionts dominated by symbionts within each period. We observed a greater number of D-colonies in the shallows, and C-colonies increased with depth, although a sharper decrease in Dcolonies with depth was observed in summer $(p=0.013)$ (Fig. 2). D-colonies were observed from 0.4-3.3 m-depth

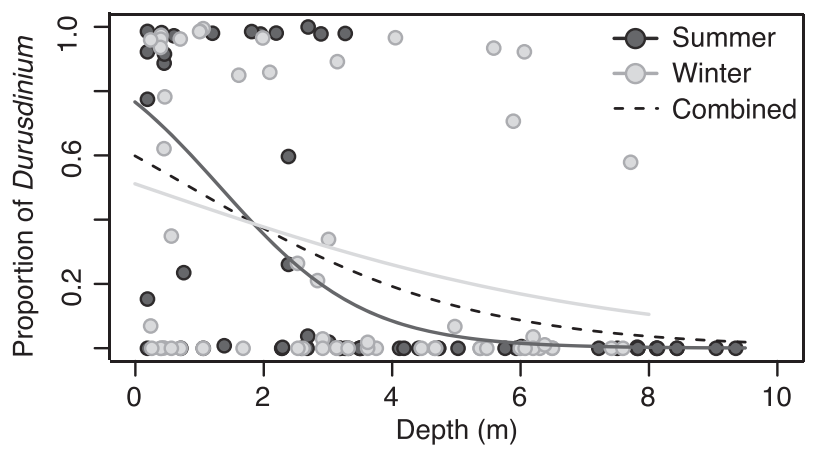

Fig. 2 Depth distribution of symbiont communities. Symbiont community in Montipora capitata colonies collected in summer (dark gray) and winter (light gray) as a function of the proportion of Durusdinium relative to Cladocopium across collection depths. Lines represent logistic regression models by each season (solid lines) and a pooled dataset (dotted line). 
Fig. 3 Multivariate analyses of coral traits. Principal component analyses (PCA) on a matrix of physiological responses and isotope values in the coral Montipora capitata evaluating the influence of a season, b location, c symbiont community, and d depth-bin. Axis values in parentheses represent the proportion of total variance associated with the respective PC. Arrows represent significant $(p<0.05)$ correlation vectors for response variables; ellipses represent $90 \%$ point densities. See Table 1 for response metric details.
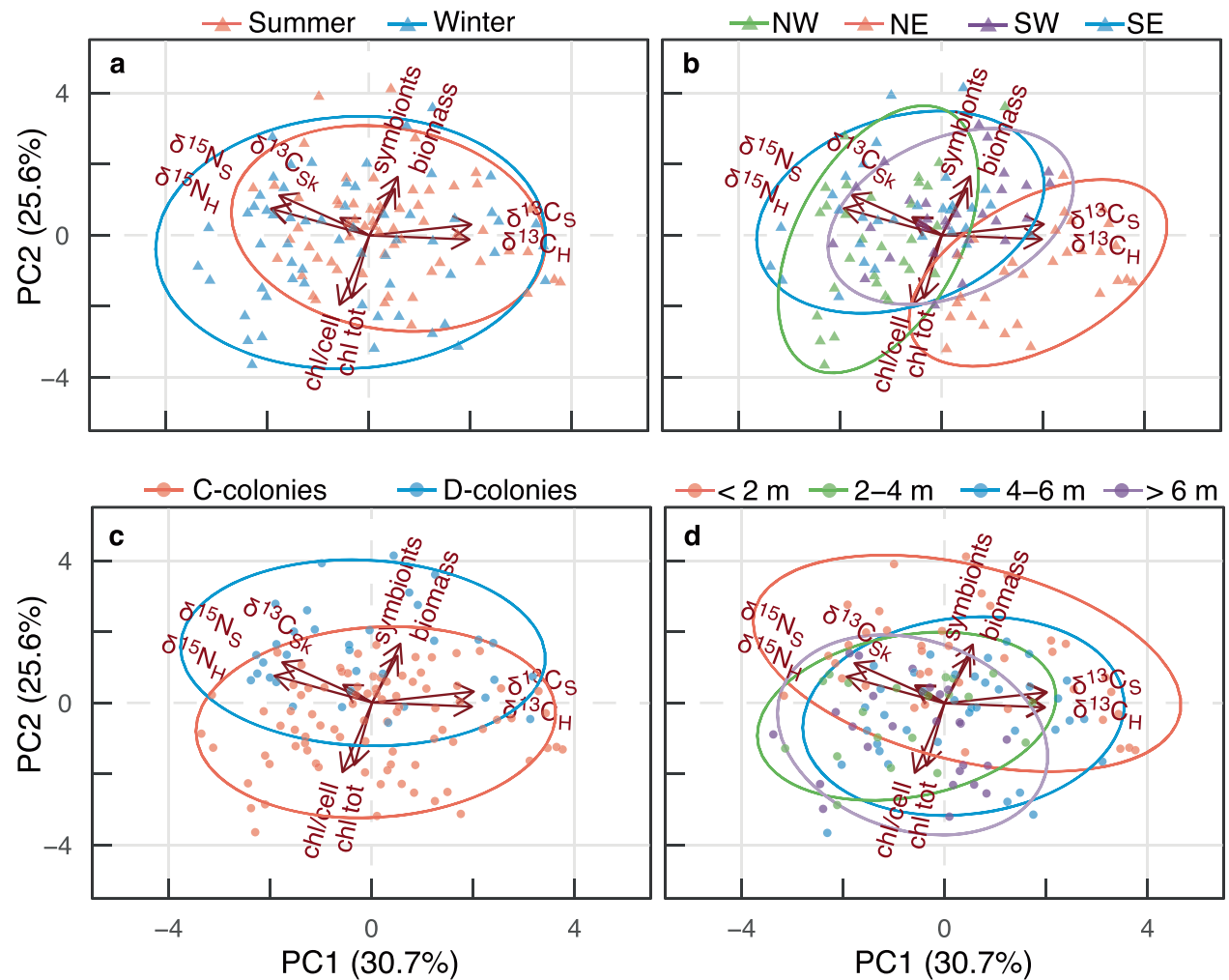

(summer) but occasionally deeper ( $7.7 \mathrm{~m}$, winter), although at low frequencies (Fig. 2). Durusdinium was also observed as a background symbiont member at community proportions of $<1-35 \%$ (mean proportion $9 \%$ ) across depths in summer $(0.8-7.8 \mathrm{~m})$ and winter $(0.2-6.5 \mathrm{~m})$.

\section{Principal component analysis of biological responses}

Two principal components (PCs) explained 56\% of the variance in coral physiological and isotope responses among seasons, locations, symbiont communities, and colony depth-bins (at 2 m-intervals) (Fig. 3). PERMANOVA results showed biological responses were most influenced by symbiont community $(p<0.001)$ followed by location $(p=0.003)$ and season $(p=0.009)$, whereas colony depthbins were non-significant ( $p=0.063)$. Overall, PC1 $(30.7 \%$ variation) separates corals with higher tissue $\delta^{13} \mathrm{C}$ values from corals with high $\delta^{15} \mathrm{~N}$ values, and PC2 (25.6\% variation) separates corals with high tissue biomass and symbiont density from those with high chlorophyll. Seasonal effects on coral responses were similar; however, greater shifts in chlorophylls and nitrogen isotope values were observed in the winter compared to the summer (Fig. 3a). Sampling locations did not produce distinct groups with the exception of the northeast location, which had higher PC1 values associated with $\delta^{13} \mathrm{C}$ values (Fig. 3b). Symbiont communities were distinguished along PC2 with D-colonies being associated with high symbiont densities and coral biomass and C-colonies having greater chlorophylls (total areal concentrations and per symbiont cell) (Fig. 3c). Zonation across depths showed corals at $<2$ m-depth were most distinct from other depths, and this mirrored the effect of symbiont community, particularly the positive correlation with PC1 and $\delta^{13} \mathrm{C}$ values (Fig. $3 \mathrm{~d}$ ). In addition, there was less variation between corals with increasing depth indicated by reduced ellipse area in deeper colonies relative to those at the surface.

\section{Physiology and isotope measurements}

Total biomass did not vary as a function of season, light, or symbiont community ( $p \geq 0.104$ ) (Table 1, S2, Fig. 4a). Symbiont densities (cells $\mathrm{cm}^{-2}$ ) were $56 \%$ higher in D-colonies relative to $\mathrm{C}$-colonies $(p<0.001)$ and increased with light availability for all colonies $(p=0.010)$, and this effect was most pronounced in winter $(p=0.004)$ (Fig. 4b). Total chlorophyll ( $\mu \mathrm{g} a+c_{2} \mathrm{~cm}^{-2}$ ) was higher in winter $(p<0.001)$ and increased as light declined $(p=0.004)$ (Table 1). Chlorophyll concentrations were equivalent between $\mathrm{C}$ - and D-colonies in the summer but were $26 \%$ higher in C-colonies during winter months $(p=0.022)$ (Fig. 4c). Chlorophyll $\left(a+c_{2}\right)$ per symbiont cell (pg cell ${ }^{-1}$ ) did not differ between seasons $(p=0.096)$, but increased as light declined $(p<0.001)$ and was $46 \%$ higher in C-colonies relative to D-colonies $(p<0.001)$ (Table 1 , 
Table 1 Statistical analysis of Montipora capitata physiology and tissue isotope values from four locations in Kāne'ohe Bay along a lightavailability gradient in summer and winter.

\begin{tabular}{|c|c|c|c|c|c|}
\hline \multirow{2}{*}{$\begin{array}{l}\text { Response } \\
\text { variable }\end{array}$} & \multicolumn{5}{|l|}{ Effects } \\
\hline & Season & Light & Symbiont & $\begin{array}{l}\text { Season } \times \\
\text { Light }\end{array}$ & $\begin{array}{l}\text { Season } x \\
\text { Symbiont }\end{array}$ \\
\hline Biomass & - & - & - & - & - \\
\hline Symbionts & - & 0.010 & $<0.001$ & 0.004 & - \\
\hline $\begin{array}{l}\text { Total } \\
\text { chlorophyll }\end{array}$ & $<0.001$ & 0.004 & $<0.001$ & - & 0.022 \\
\hline $\begin{array}{l}\text { Chlorophyll } \\
\text { per cell }\end{array}$ & - & $<0.001$ & $<0.001$ & - & - \\
\hline$\delta^{13} \mathrm{C}_{\mathrm{H}}$ & - & $<0.001$ & $<0.001$ & - & 0.031 \\
\hline$\delta^{13} \mathrm{C}_{\mathrm{S}}$ & - & $<0.001$ & $<0.001$ & - & 0.001 \\
\hline$\delta^{13} \mathrm{C}_{\mathrm{H}-\mathrm{S}}$ & 0.002 & - & $<0.001$ & 0.040 & 0.037 \\
\hline$\delta^{13} \mathrm{C}_{\mathrm{Sk}}$ & 0.009 & - & - & - & - \\
\hline$\delta^{15} \mathrm{~N}_{\mathrm{H}}$ & - & 0.040 & - & - & - \\
\hline$\delta^{15} \mathrm{~N}_{\mathrm{S}}$ & - & - & 0.008 & - & 0.017 \\
\hline$\delta^{15} \mathrm{~N}_{\mathrm{H}-\mathrm{S}}$ & - & 0.018 & 0.002 & - & $<0.001$ \\
\hline $\mathrm{C}: \mathrm{N}_{\mathrm{H}}$ & - & - & - & - & - \\
\hline $\mathrm{C}: \mathrm{N}_{\mathrm{S}}$ & - & - & - & - & - \\
\hline
\end{tabular}

Table information shows significant model effects $(p<0.05)$; dashed lines indicate no significant effects $(p>0.05)$. Subscripts indicate either host (H) or symbiont (S) tissues, or their relative difference (H-S), and skeletal carbonates (Sk).

Season summer or winter; Light light at depth of collection; Symbiont either Cladocopium (formerly clade C) or Durusdinium (formerly clade D) dominated symbiont community

Fig. 4d). As a random effect, location accounted for 9-32\% model variance for physiological responses (Fig. S6).

The carbon isotope composition of both coral host $\left(\delta^{13} \mathrm{C}_{\mathrm{H}}\right)$ and the symbiont algae $\left(\delta^{13} \mathrm{C}_{\mathrm{S}}\right)$ became progressively ${ }^{13} \mathrm{C}$-depleted (i.e., lower $\delta^{13} \mathrm{C}$ values) as light availability declined $(p<0.001)$ (Table 1, S3, Fig. 5a, b). Host and symbiont $\delta^{13} \mathrm{C}$ values in $\mathrm{C}$-colonies were ${ }^{13} \mathrm{C}$-enriched (i.e., higher $\delta^{13} \mathrm{C}$ values) relative to D-colonies $(p<0.001)$, particularly in the summer $(p \leq 0.031)$. Host $\delta^{13} \mathrm{C}$ values were $1.6 \%$ and $0.8 \%$ o higher in C-colonies relative to $\mathrm{D}$ colonies in summer and winter, respectively (Fig. 5a), whereas symbiont $\delta^{13} \mathrm{C}$ values were $1.5 \%$ o higher in $\mathrm{C}$ colonies in summer but comparable between both $\mathrm{C}$ - and $\mathrm{D}$ colonies in winter (Fig. 5b). The difference in host and symbiont carbon isotope values $\left(\delta^{13} \mathrm{C}_{\mathrm{H}-\mathrm{S}}\right)$ differed between C- and D-colonies $(p<0.001)(0.3 \%)$, and this was driven by greater differences in $\delta^{13} \mathrm{C}_{\mathrm{H}-\mathrm{S}}$ during the winter. In winter, $\delta^{13} \mathrm{C}_{\mathrm{H}-\mathrm{S}}$ increased as light decreased with depth $(p=$ $0.040)$ and was lower in D-colonies $(p=0.037)$ (Table 1 , S3, Fig. 5c). Skeletal carbonate $\delta^{13} \mathrm{C}$ values (i.e., $\delta^{13} \mathrm{C}_{\mathrm{Sk}}$ ) varied across samples, but the range $(-4$ to $-0.4 \%$ o $)$ and average $\delta^{13} \mathrm{C}_{\mathrm{Sk}}$ values (ca. $-2.5 \%$ ) were consistent among seasons $(<0.5 \%$ o change) and did not systematically decline under low light $(p=0.639)$ (Fig. S7). Location accounted for $17-27 \%$ of all carbon isotope model variances (Fig. S6).
Tests of the influence of symbiont traits on isotope values (Fig. S8a-c) revealed $\delta^{13} \mathrm{C}_{\mathrm{S}}$ values increased with symbiont density in the winter, but not summer, for Ccolonies $\left(p<0.001, R^{2}=0.360\right)$ and D-colonies $(p=0.007$, $\left.R^{2}=0.708\right) . \delta^{13} \mathrm{C}_{\mathrm{S}}$ values were not related to changes in total chlorophyll in either season for C-or D-colonies ( $p \geq$ 0.414). In C-colonies alone, $\delta^{13} \mathrm{C}_{\mathrm{S}}$ values increased as chlorophyll cell ${ }^{-1}$ declined in summer $\left(p=0.004, R^{2}=\right.$ $0.173)$ and winter $\left(p=0.030, R^{2}=0.115\right) . \delta^{13} C_{H}$ values for $\mathrm{C}$ - and D-colonies exhibited similar effects as observed for $\delta^{13} \mathrm{C}_{\mathrm{S}}$ (data not shown). $\delta^{13} \mathrm{C}_{\mathrm{H}-\mathrm{S}}$ values were only influenced by symbiont densities and became more positive as symbiont densities declined in summer D-colonies $(p=$ $\left.0.004, R^{2}=0.478\right)$ and in both winter C-colonies $(p=$ $\left.0.014, R^{2}=0.145\right)$ and D-colonies $\left(p=0.007, R^{2}=0.361\right)$ (Fig. S9).

Nitrogen isotope values of the coral host and symbiont did not show meaningful change across seasons, light availabilities, or symbiont communities (Table 1, S3, Fig. S10) (see Supplemental Materials). Molar ratios of carbon:nitrogen $(\mathrm{C}: \mathrm{N})$ in host and symbionts showed no significant effects $(p \geq 0.134)$ (Table 1, S3, Fig. S11). Location explained a large portion of variance for $\delta^{15} \mathrm{~N}_{\mathrm{H}}$ (75\%) and $\delta^{15} \mathrm{~N}_{\mathrm{S}}(80 \%)$ models but less $(<20 \%)$ in $\delta^{15} \mathrm{~N}_{\mathrm{H}-\mathrm{S}}$ and C:N models (Fig. S6). 


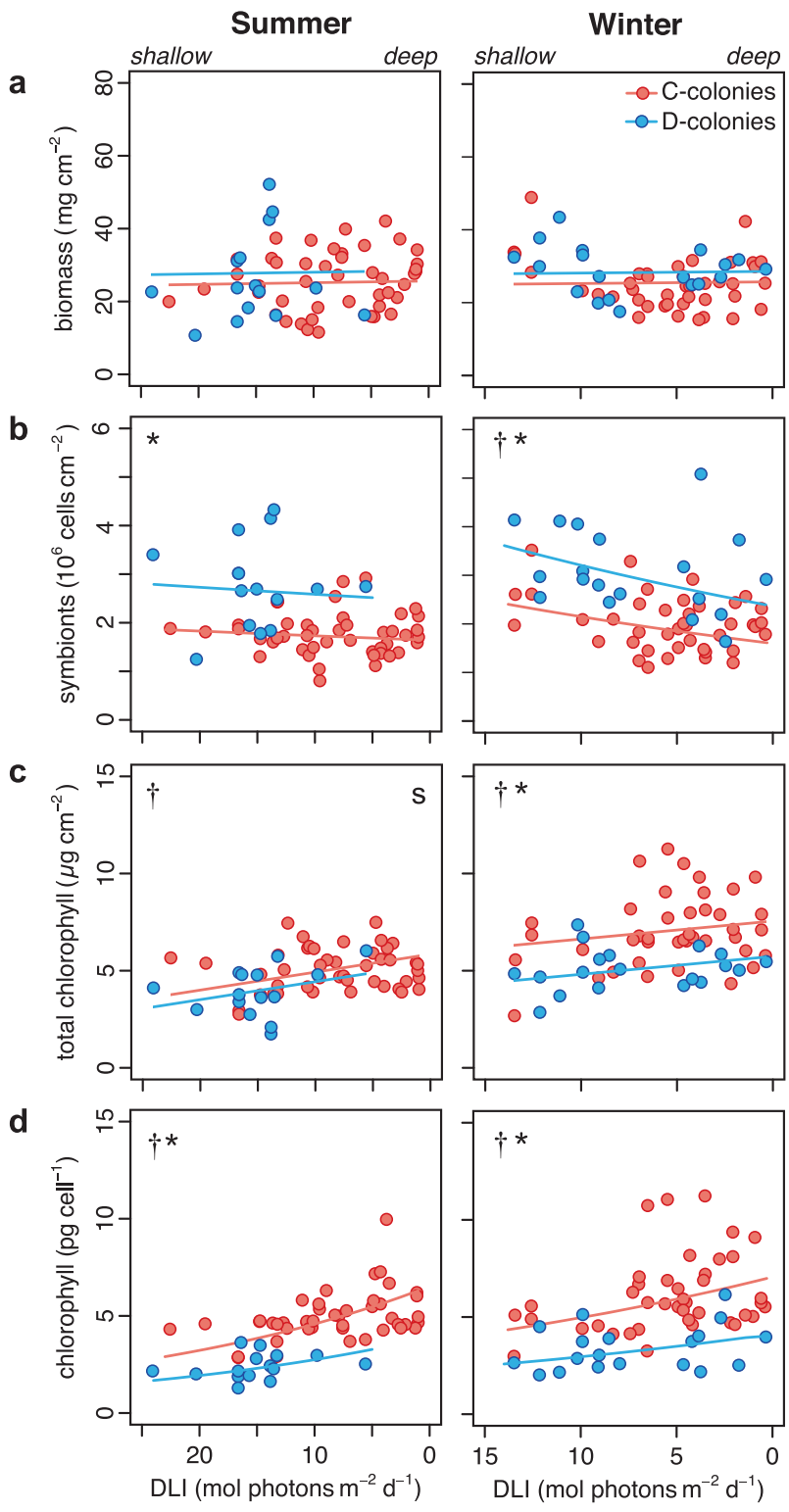

Fig. 4 Physiological traits. Physiological metrics for Montipora capitata colonies dominated by C (Cladocopium) or D (Durusdinium) symbionts collected from four Kāne'ohe Bay reef locations in summer (left) and winter (right) spanning a light availability gradient across $<1-10$ m-depth. Area-normalized a total tissue biomass, b symbiont cell densities, $\mathbf{c}$ total chlorophyll $\left(a+c_{2}\right)$, and $\mathbf{d}$ chlorophyll per symbiont cell. Solid lines represent the linear mixed effect model fits. Symbols indicate significant differences $(p<0.05)$ between symbiont communities $(*)$, in response to light $(\dagger)$, and between seasons $(s)$.

\section{Discussion}

Symbiodiniaceae diversity, function, and community physiological traits have a clear influence on coral stable isotope values and these effects manifested across a narrow depth gradient in relation to rapid light attenuation. Speciesspecific symbiont attributes, including higher symbiont densities, lower chlorophylls per cell, and lower $\delta^{13} \mathrm{C}$ values indicate lower rates of carbon assimilation/translocation and
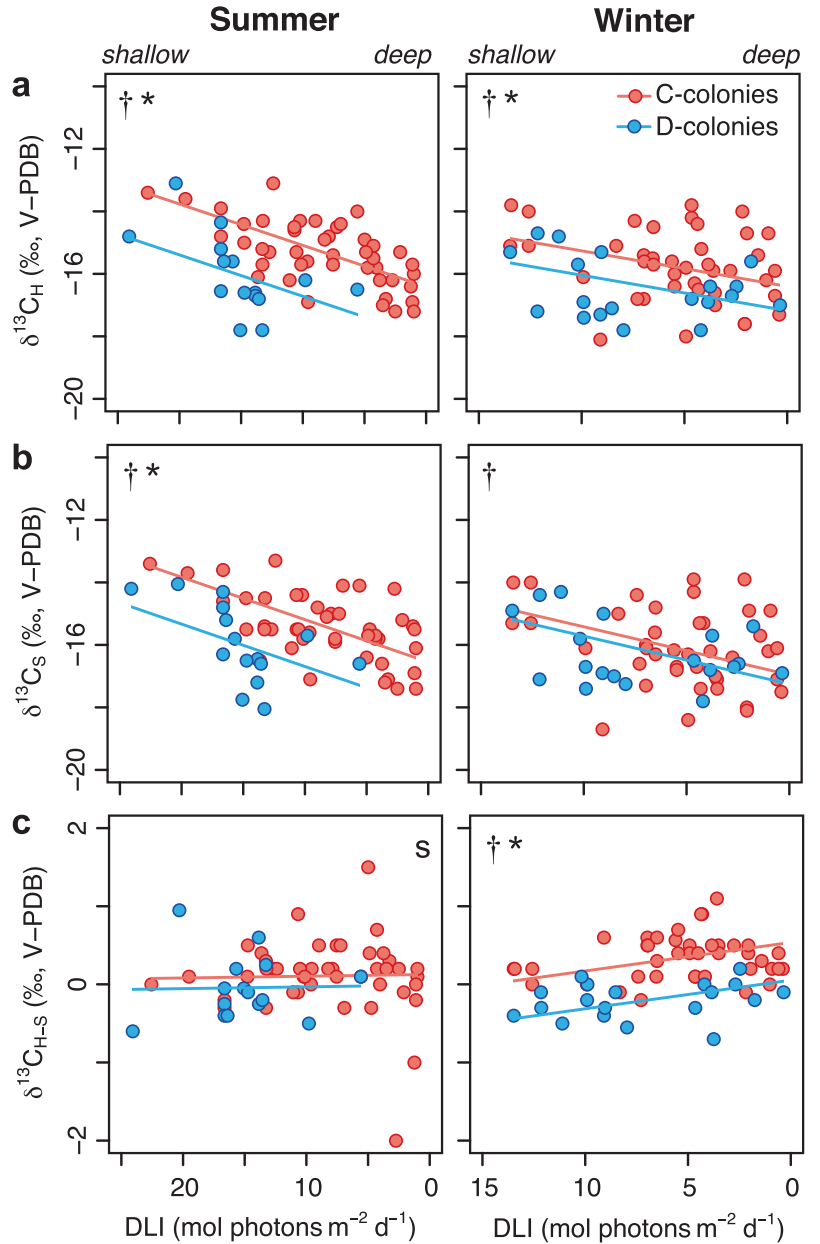

Fig. 5 Stable isotope values. Carbon stable isotope values for Montipora capitata colonies dominated by C (Cladocopium) or D (Durusdinium) symbionts collected from four Kāne'ohe Bay reef locations in summer (left) and winter (right) spanning a light availability gradient across $<1-10 \mathrm{~m}$-depth. Values are for a coral host $\left(\delta^{13} \mathrm{C}_{\mathrm{H}}\right)$ b symbiont algae $\left(\delta^{13} \mathrm{C}_{\mathrm{S}}\right)$ and $\mathbf{c}$ their relative difference $\left(\delta^{13} \mathrm{C}_{\mathrm{H}-\mathrm{S}}\right)$ in permil (\%o) relative to carbon standards (Vienna Pee Dee Belemnite: V-PDB). Solid lines represent linear mixed effect model fits. Symbols indicate significant differences $(p<0.05)$ between symbiont communities $(*)$, in response to light $(\dagger)$, and between seasons $(s)$.

potential host exploitation by Durusdinium glynnii. However, neither environmental nor symbiont community effects resulted in greater heterotrophic nutrition, suggesting photoacclimation may be central to coping with energetic tradeoffs incurred by corals in low-light environments as well as in association with opportunistic symbionts, such as D. glynnii. Finally, we identify symbiont community function as an important, yet often overlooked, component to isotopic investigations into coral physiological ecology.

Light attenuation in Kāne'ohe Bay was rapid across a narrow depth gradient with maximum PAR at $1 \mathrm{~m}$-depth across all sites (ca. 1400-2300 $\mu \mathrm{mol}$ photons $\mathrm{m}^{-2} \mathrm{~s}^{-1}$ ) attenuated to $50-350 \mu \mathrm{mol}$ photons $\mathrm{m}^{-2} \mathrm{~s}^{-1}$ at $8 \mathrm{~m}$-depthequivalent to PAR attenuation observed at $40-70 \mathrm{~m}$ in coral reefs of the Red Sea [73] and 20-40 m in the Caribbean 
[74, 75]. Therefore, depth-dependent changes in light availability is a principal force acting to partition $M$. capitata symbiont communities with a greater frequency of Durusdinium observed at shallow depths across seasons and reef locations. This depth-dependent distribution in response to reduced light availability can in part be explained by close proximities to multiple watersheds and high concentrations of fine-grained particles that dominate inshore Kāne'ohe Bay reefs [54], which settle slowly and are easily re-suspended, creating significant and persistent light attenuation [76].

Globally, the prevalence of Durusdinium is higher on human-impacted reefs, including those experiencing high temperatures and/or recent thermal stress and high rates of sedimentation [77]. Therefore, the shallow-water dominance of D. glynnii in Kāne 'ohe Bay M. capitata suggests a greater capacity for this species to tolerate a combination of more frequent temperature anomalies [20, 51] and high irradiances [35] compared to Cladocopium spp. In Hawai'i, reports of Durusdinium have been limited to $M$. capitata from Kāne'ohe Bay, which has a history of persistent human impacts (dredging, sewage outflow) and high frequency of thermal stress anomalies [20, 78]. This combination of human impacts and thermal stress anomalies may have allowed a niche for Durusdinium to exploit, while also driving local adaptation in the coral hosts for increased tolerance to thermal stress [79]. While Durusdinium prevalence in shallow depths (ca. $<3 \mathrm{~m}$ ) indicates a tolerance to elevated light and temperature, the rarity of D-colonies at depth also indicate Symbiodiniaceae niche partitioning in response to light availability and perhaps a limited capacity for Durusdinium to adapt to low PAR or in response to changing light spectra [73, 80]. Intraspecific shifts in symbiont communities generally occur at deeper depths, for instance Stylophora pistillata transitions from Symbiodinium microadriaticum (ITS2: A1) $(<10 \mathrm{~m})$ to Cladocopium spp. ( $>40 \mathrm{~m})$ in the Red Sea [17], and Seriatopora hystrix transitions from Durusdinium $(<23 \mathrm{~m})$ to Cladocopium (>23 m) in western Australia [35]. However, high turbidity in Kāne'ohe Bay has resulted in $M$. capitata symbiont community depth zonation to within a few meters $(<2 \mathrm{~m})$ of the surface ([36]; this study).

D-colonies had lower $\delta^{13} \mathrm{C}$ values, indicating greater isotope fractionation and/or lower rates of carbon assimilation and translocation to the coral host compared to C-colonies [14, 15]. While $\delta^{13} \mathrm{C}$ values are also influence by tissue properties, sources of inorganic carbon, and the contribution (and composition) of respiration $\mathrm{CO}_{2}$ to the internal carbon pool [81], patterns observed here provide indirect evidence consistent with lower rates of photosynthesis and carbon fixation. M. capitata did not show signs of changes in heterotrophic feeding in response to changing light conditions, seasons, or due to hosting different symbiont species. However, substantial and persistent effects of symbiont community on isotope values were observed, which in conjunction with physiological attributes of the holobionts, reveal differing capacities of Cladocopium spp. and D. glynnii to fix and translocate carbon to their hosts. Photoacclimation had a clear influence on $M$. capitata host and symbiont $\delta^{13} \mathrm{C}$ values, indicated by a positive relationship with symbiont densities in winter and a negative relationship with photopigmentation (pg cell ${ }^{-1}$ ) (Fig. S8), and these effects were more pronounced in $\mathrm{C}$-colonies.

Changes in symbiont densities and photopigmentation are important photoacclimation responses to maximize light-use efficiency in reef corals [42] and influence holobiont energetics, calcification [29], and sensitivity to thermal stress [82]. Changes in chlorophylls, however, are but one mechanism corals employ to optimize light capture and attenuate damage from photoinhibition. Photoacclimation in shallow corals can also include increased concentrations in photoprotective pigments of the symbiont (xanthophyll, $\beta$-carotene) and host (fluorescent proteins), or greater dissipation of absorbed light-energy through non-photochemical quenching (i.e., NPQ) [83]. Similar mechanisms of modulating pigmentation and light-energy dissipation are also used by corals in deep-water habitats acclimated to low (and variable) light intensity of different spectral compositions. In the case of the latter, host-derived photoconvertible red fluorescent proteins (pcRFPs) appear to contribute to low-light adaptation in corals through the transformation of blue-to-orange light wavelengths that benefit symbiont light capture in deep-water corals [84]. Such changes in host pigmentation have not been tested in $M$. capitata but may be of importance considering this species exhibits depth-dependent distributions of two distinct color morphs (orange vs. brown) [36].

We observed D-colonies to have 54-58\% greater symbiont densities and $0.8-1.6 \%$ lower $\delta^{13} \mathrm{C}$ values compared to C-colonies; however, C-colonies had $46 \%$ higher chlorophyll cell ${ }^{-1}$ and showed greater potential to regulate areal and symbiont cell-specific chlorophyll concentrations in response to changing environmental conditions. While Symbiodiniaceae cell size can influence symbiont densities, the coccoid cell sizes for other Durusdinium and Cladocopium species overlap [1, 50]. High symbiont densities increase symbiont self-shading, which can reduce internal light values by $90 \%$ relative to those at the colony surface [85] and cause declines in net photosynthesis through light and/or carbon limitations. In both cases, reductions in photosynthesis rates (inferred here by lower $\delta^{13} \mathrm{C}$ values) reduce nutritional benefits to the host [82]. Changes in photosynthesis relative to respiration (P:R) can also be influenced by symbiont communities and environmental contexts, where metabolic savings from lower respiration 
rates with increasing depth (higher $\mathrm{P}: \mathrm{R}$ ) transition to metabolic costs (lower P:R) in symbionts unable to acclimate to light limitations [35]. Therefore, the clear differences in symbiont traits and isotope values between $\mathrm{C}$ - and D-colonies provide evidence for different physiological and biochemical processes in these two holobionts. In addition, the greater ability for $\mathrm{C}$-colonies to photoacclimate in response to changing light-availability indicate light as a driver in the niche partitioning of these symbiont species.

Differences in symbiont densities can also be influenced by Symbiodiniaceae growth rates and/or responses to nutrient availability [86]. For example, symbiont-derived photosynthates stimulate the recycling of ammonium waste by the host and nitrogen incorporation into amino acids, serving as a negative-feedback loop regulating symbiont densities by limiting nitrogen to the symbiont [87]. Paradoxically, reduced symbiont photosynthesis increases nitrogen availability to the symbiont, and as a result, symbiont biomass and densities may increase. Similarly, corals exposed to sub-bleaching thermal stress experience reduced carbon transferred from their symbionts, but symbiont carbon and nitrogen assimilation and growth increases [18]. Symbiont community effects on host, in particular through effects on ammonium metabolism, may also influence nitrogen availability and increase symbiont growth and densities [31]. For instance, Exaiptasia pallida anemones infected with Durusdinium trenchii increased the transport of ${ }^{15} \mathrm{~N}$-labeled products through the urea cycle and had greater glutamine pool enrichment (a primary enzyme in the assimilation of ammonium) compared to Breviolum minutum-hosting anemones, which did not show urea cycle feedback but had greater glutamine synthetase enzyme abundance $[31,88]$. Such effects on host metabolism dictated by Symbiodiniaceae community may serve to regulate nitrogen availability and symbiont densities and should be further tested in reef corals.

Poor cellular communication and compatibility between symbiont partners in opportunistic or heterologous symbionts can elicit host immune responses [88] and adversely affect host performance [29]. Reduced communication and hostsymbiont compatibility, therefore, may explain why shifts in symbiont communities are host specific and are generally limited to corals living near limits of their environmental tolerance [23]. Nevertheless, different capacities for Symbiodiniaceae to assimilate carbon and nitrogen in support of host growth [11, 14, 25, 29] appear to also extend to influences on host metabolism and resource allocation [31, 87], with one possible outcome being slower rates of production benefiting symbiont growth and favoring opportunism. Identifying the metabolic tradeoffs from hosting different Symbiodiniaceae communities requires further study, but may prove to be mechanisms by which symbionts benefit while imparting a metabolic cost to the coral host.
Montipora capitata tissue (host, symbionts) and skeletal $\delta^{13} \mathrm{C}$ values declined as light decreased, in agreement with increased carbon isotope fractionation as carbon fixation rates decline in low-light environments [45, 61]. During periods of high coral photosynthesis the internal carbon pool becomes enriched in ${ }^{13} \mathrm{C}$ (higher $\delta^{13} \mathrm{C}$ values) as dissolved inorganic carbon enriched in ${ }^{12} \mathrm{C}$ is preferentially fixed [81]. As a result, the discrimination (i.e., isotope fractionation) against heavy isotopes is reduced and $\delta^{13} \mathrm{C}$ values of photosynthetic products increase [89]. Conversely, reductions in carbon demand/photosynthesis allow for greater isotope discrimination and overall lower $\delta^{13} \mathrm{C}$ values in photosynthetic products and the internal carbon pool. In our study of $M$. capitata, we observed spatiotemporal changes in $\delta^{13} \mathrm{C}$ values to correspond between the host and symbiont, resulting in limited relative differences in carbon isotope values (i.e., $\delta^{13} \mathrm{C}_{\mathrm{H}-\mathrm{S}}$ ), a commonly applied metric for greater heterotrophy $\left(\delta^{13} \mathrm{C}_{\mathrm{H}-\mathrm{S}}\right.$ values $\left.<0\right)$ relative to autotrophy $\left(\delta^{13} \mathrm{C}_{\mathrm{H}-\mathrm{S}}\right.$ values $\left.>0\right)$ [45-47]. In fact, $\delta^{13} \mathrm{C}_{\mathrm{H}-\mathrm{S}}$ values became more positive as depth increased, which is opposite to the expected positive correlations between depth and coral heterotrophic nutrition [45]. Considering $\delta^{13} \mathrm{C}_{\mathrm{H}-\mathrm{S}}$ would be expected to decline as symbiont densities are reduced in stressed corals, we further explored the relationship between $\delta^{13} \mathrm{C}_{\mathrm{H}-\mathrm{S}}$ and symbiont densities. Again, we find unexpected results: $\delta^{13} \mathrm{C}_{\mathrm{H}-\mathrm{S}}$ generally increases and becomes more positive in corals as symbiont densities decline (Fig. S9). This relationship may reflect optimal symbiont densities that maximize net photosynthesis and reduce cell shading in healthy corals. Nevertheless, these findings do not support greater heterotrophy in corals in response to light attenuation or reductions in symbiont densities and cast doubt on the effectiveness of using $\delta^{13} \mathrm{C}_{\mathrm{H}}$ $\mathrm{S}$ as a proxy for greater heterotrophic nutrition in healthy, non-bleached corals as well as those undergoing symbiont loss due to environmental stress.

Similar disagreements in using $\delta^{13} \mathrm{C}_{\mathrm{H}-\mathrm{S}}$ values to infer depth-dependent changes in coral nutrition in other studies have been clarified using compound-specific isotope analyses. For instance, Stylophora pistillata and Favia favus showed no change in $\delta^{13} \mathrm{C}_{\mathrm{H}-\mathrm{S}}$ across depths $(<60 \mathrm{~m})$ in the Red Sea. However, examining the $\delta^{13} \mathrm{C}$ values in lipids between host and symbionts suggested an increase in heterotrophic carbon usage by $S$. pistillata in lipid synthesis below $20 \mathrm{~m}$ but consistently low $\delta^{13} \mathrm{C}$-lipid values in $F$. favus across depths, suggesting high and invariable heterotrophic contributions to lipid biosynthesis in $F$. favus [48]. In bleached and post-bleaching recovered $M$. capitata and Porites compressa ${ }^{13} \mathrm{C}$ values showed poor relationships with bleaching history and did not suggest a greater capacity for heterotrophic feeding; instead $\delta^{13} \mathrm{C}$ values were best explained by an isotope mass balance accounting for differences in proteins:lipids:carbohydrates in coral tissues 
[33]. It is therefore important for uncertainties in isotope values to be further explored in symbiotic mixotrophic organisms and for caution to be applied in the interpretation of these data to infer trophic plasticity. In the present study, changes in host and symbiont $\delta^{13} \mathrm{C}$ values appear to instead be an effect of the interaction between light-availability and symbiont community, in agreement with rapid internal cycling and a shared carbon source of the symbiont partners ([49, 61]). While M. capitata biomass and C:N was not influenced by symbiont types or environmental conditions, it is important for future studies to also consider the role of Symbiodiniaceae on coral metabolite profiles [31, 90, 91] which may influence tissue biochemical composition and isotope values [33, 35, 92, 93].

Skeletal carbonate $\delta^{13} \mathrm{C}$ values (i.e., $\delta^{13} \mathrm{C}_{\mathrm{Sk}}$ ) are expected to become more negative as P:R decline [94] or as an effect of greater metabolic fractionation and increased respiratoryderived carbon with low $\delta^{13} \mathrm{C}$ values used in biomineralization [95]. However, M. capitata showed relatively small differences in $\delta^{13} \mathrm{C}_{\mathrm{Sk}}$ and $\delta^{13} \mathrm{C}_{\mathrm{H}-\mathrm{S}}$ values across light environments and seasons, suggesting a dominance of autotrophic sources and the maintenance of nutrient recycling between partners. Corals also did not show a decrease in $\delta^{15} \mathrm{~N}$ values with depth, as would be predicted as photosynthesis becomes light-limited or if corals are feeding on a prey source with low $\delta^{15} \mathrm{~N}$ values [96]. Considering the $\delta^{15} \mathrm{~N}$ values of heterotrophic sources in seawater (Fig. S4), corals and their symbionts most resemble the $\delta^{15} \mathrm{~N}$ values of dissolved inorganic nitrogen (3.8-4.9\%o [33]) and not plankton endmembers. Therefore, M. capitata appears to have maintained high rates of photosynthesis (or P:R) as to not show systematic decreases in $\delta^{15} \mathrm{~N}$ or ${ }^{13} \mathrm{C}_{\mathrm{Sk}}$ values and does not show evidence for increased heterotrophy with depth. Predator ${ }^{15} \mathrm{~N}$-enrichment factors typically observed in food webs $(\sim 3.5 \%$ ) appear absent or substantially attenuated in corals. The cause for this attenuated trophic enrichment may be nitrogen recycling, wherein symbionts uptake host excreta with low $\delta^{15} \mathrm{~N}$ values (i.e., ${ }^{14} \mathrm{NH}_{4}$ ) for amino acid synthesis and translocate a greater proportion of ${ }^{14} \mathrm{~N}$-products to the host, effectively lowering $\delta^{15} \mathrm{~N}$ values for the holobiont [62]. However, a degree of predator enrichment would still be expected as coral predators and their symbiont retain "heavy" isotope products and exchange "light" isotope products, unless internally recycled nitrogen dominates the host's nitrogen budget. Alternatively, the isotopic signal originating in prey capture may be overwhelmed by internal and external DIN uptake and nitrogen recycling by Symbiodiniaceae. Further experimental measurements of isotopic compositions of nitrogen sources and downstream products in host and symbiont tissues (i.e., amino acids) may provide a way to clarify heterotrophic influences on coral isotope values (for carbon, see ref. [97]).

\section{Conclusion}

Our analyses of $M$. capitata, therefore, provide three central findings. First, symbiont communities are capable of influencing the isotope values of the holobiont and this fact should be considered in the interpretation and sampling of corals across ecological gradients where symbiont species are partitioned. Second, proxies for assessing greater contributions of heterotrophy relative to autotrophy are more complex than previously recognized [48] and variance originating in host and symbiont $\delta^{13} \mathrm{C}$ values-including proxies for nutritional plasticity (i.e., $\delta^{13} \mathrm{C}_{\mathrm{H}-\mathrm{S}}$ ) - may be influenced by physiological factors (i.e., symbiont densities, photoacclimation) unrelated to prey capture. Finally, more nuanced approaches are needed to disentangle the influences of environmental and biological effects on coral carbon and nitrogen isotope values, including compound specific analyses of fatty acids and amino acids [5, 47, 48, 93] and accounting for shifts in biomass composition [33]. Therefore, our findings reinforce the conclusion that facultative shifts in heterotrophic nutrition where they occur are speciesspecific [48, 98, 99] and context-dependent, perhaps limited to more extreme physiological conditions or to geographic locations favoring mixotrophy (i.e., high nearshore productivity [47]). Further tests of symbiont community effects on isotope values and the energetic consequences of flexible symbiont associations in reef corals should be prioritized in future studies [100].

Acknowledgements All corals were collected under State of Hawai ' $\mathrm{i}$ Division of Aquatic Resources Special Activity Permit 2016-55 and 2018-03. We thank R. Cunning, T. Innis, R. Ritson-Williams, A. Huffmyer, J. Levy, W. Goodell for field assistance, A. Amend, R. Cunning, E. Lenz, S. Matsuda, A. Moran, C. Sabine for comments and fruitful discussions, and W. Ko, N. Wallsgrove, and H. Spero for stable isotope analysis. We dedicate this publication to the memory of our dear friend, colleague, and mentor Dr. Ruth Gates. This is SOEST contribution number 10869 and HIMB contribution number 1777 .

Funding CBW was supported by funds from the Colonel Willys E. Lord \& Sandina L. Lord Endowed Scholarship, UH Mānoa SOEST/ HIGP Denise B. Evans Fellowship in Oceanographic Research, and an Environmental Protection Agency STAR Fellowship Assistance Agreement (FP-91779401-1). The views expressed in this publication have not been reviewed or endorsed by the EPA and are solely those of the authors.

\section{Compliance with ethical standards}

Conflict of interest The authors declare that they have no conflict of interest.

Publisher's note Springer Nature remains neutral with regard to jurisdictional claims in published maps and institutional affiliations. 
Open Access This article is licensed under a Creative Commons Attribution 4.0 International License, which permits use, sharing, adaptation, distribution and reproduction in any medium or format, as long as you give appropriate credit to the original author(s) and the source, provide a link to the Creative Commons license, and indicate if changes were made. The images or other third party material in this article are included in the article's Creative Commons license, unless indicated otherwise in a credit line to the material. If material is not included in the article's Creative Commons license and your intended use is not permitted by statutory regulation or exceeds the permitted use, you will need to obtain permission directly from the copyright holder. To view a copy of this license, visit http://creativecommons. org/licenses/by/4.0/.

\section{References}

1. LaJeunesse TC, Parkinson JE, Gabrielson PW, Jeong HJ, Reimer JD, Voolstra CR, et al. Systematic revision of Symbiodiniaceae highlights the antiquity and diversity of coral endosymbionts. Curr Biol. 2018;28:2570-80.

2. Wild C, Hoegh-Guldberg O, Naumann MS, Colombo-Pallotta MF, Ateweberhan M, Fitt WK, et al. Climate change impedes scleractinian corals as primary reef ecosystem engineers. Mar Freshw Res. 2011;62:205-15.

3. Muscatine L, Cernichiari E. Assimilation of photosynthetic products of zooxanthellae by a reef coral. Biol Bull. 1969;137:506-23.

4. Papina M, Meziane T, van Woesik R. Symbiotic zooxanthellae provide the host-coral Montipora digitata with polyunsaturated fatty acids. Comp Biochem Physiol B Biochem Mol Biol. 2003;135:533-7.

5. Baumann J, Grottoli AG, Hughes AD, Matsui Y. Photoautotrophic and heterotrophic carbon in bleached and nonbleached coral lipid acquisition and storage. J Exp Mar Bio Ecol. 2014;461:469-78.

6. Gattuso J-P, Allemand D, Frankignoulle M. Photosynthesis and calcification at cellular, organismal and community levels in coral reefs: a review on interactions and control by carbonate chemistry. Integr Comp Biol. 1999;39:160-83

7. Muscatine L, Falkowski PG, Porter JW, Dubinsky Z. Fate of photosynthetic fixed carbon in light- and shade-adapted colonies of the symbiotic coral Stylophora pistillata. Proc R Soc Lond B. 1984;222:181-202.

8. Rahav O, Dubinsky Z, Achituv Y, Falkowski PG. Ammonium metabolism in the zooxanthellate coral, Stylophora pistillata. Proc R Soc Lond B. 1989;236:325-37.

9. Hughes TP, Barnes ML, Bellwood DR, Cinner JE, Cumming GS, Jackson JBC, et al. Coral reefs in the Anthropocene. Nature. 2017;546:82-90.

10. Vega Thurber RL, Burkepile DE, Fuchs C, Shantz AA, McMinds R, Zaneveld JR. Chronic nutrient enrichment increases prevalence and severity of coral disease and bleaching. Glob Chang Biol. 2014;20:544-54.

11. Little AF, van Oppen MJH, Willis BL. Flexibility in algal endosymbioses shapes growth in reef corals. Science. 2004:304:1492-4.

12. Pochon X, Putnam HM, Gates RD. Multi-gene analysis of Symbiodinium dinoflagellates: a perspective on rarity, symbiosis, and evolution. PeerJ. 2014;2:e394.

13. Sampayo EM, Dove S, Lajeunesse TC. Cohesive molecular genetic data delineate species diversity in the dinoflagellate genus Symbiodinium. Mol Ecol. 2009;18:500-19.

14. Pernice M, Dunn SR, Tonk L, Dove S, Domart-Coulon I, Hoppe $\mathrm{P}$, et al. A nanoscale secondary ion mass spectrometry study of dinoflagellate functional diversity in reef-building corals. Environ Microbiol. 2015;17:3570-80.

15. Stat M, Morris E, Gates RD. Functional diversity in coral-dinoflagellate symbiosis. Proc Natl Acad Sci USA. 2008;105:9256-61.

16. Baker AC. Flexibility and specificity in coral-algal symbiosis: Diversity, ecology, and biogeography of Symbiodinium. Annu Rev Ecol Evol Syst. 2003;34:661-89.

17. Ezzat L, Fine M, Maguer J-F, Grover R, Ferrier-Pagès C. Carbon and nitrogen acquisition in shallow and deep holobionts of the scleractinian coral S. pistillata. Front Mar Sci. 2017;4:102.

18. Baker DM, Freeman CJ, Wong JCY, Fogel ML, Knowlton N. Climate change promotes parasitism in a coral symbiosis. ISME J. 2018;12:921-30.

19. Glynn PW, Maté JL, Baker AC, Calderón MO. Coral bleaching and mortality in Panama and Ecuador During the 1997-1998 El Niño-Southern Oscillation event: Spatial/temporal patterns and comparisons with the 1982-1983 event. Bull Mar Sci. 2001;69:79-109.

20. Stat M, Pochon X, Franklin EC, Bruno JF, Casey KS, Selig ER, et al. The distribution of the thermally tolerant symbiont lineage (Symbiodinium clade D) in corals from Hawaii: correlations with host and the history of ocean thermal stress. Ecol Evol. 2013;3:1317-29.

21. van Oppen MJ, Palstra FP, Piquet AM, Miller DJ. Patterns of coral-dinoflagellate associations in Acropora: significance of local availability and physiology of Symbiodinium strains and host-symbiont selectivity. Proc Biol Sci. 2001;268:1759-67.

22. Matthews JL, Crowder CM, Oakley CA, Lutz A, Roessner U, Meyer E, et al. Optimal nutrient exchange and immune responses operate in partner specificity in the cnidarian-dinoflagellate symbiosis. Proc Natl Acad Sci USA. 2017;114:13194-9.

23. Baker DM, Andras JP, Jordán-Garza AG, Fogel ML. Nitrate competition in a coral symbiosis varies with temperature among Symbiodinium clades. ISME J. 2013;7:1248-51.

24. Lesser MP, Stat M, Gates RD. The endosymbiotic dinoflagellates (Symbiodinium sp.) of corals are parasites and mutualists. Coral Reefs. 2013;32:603-11.

25. Cantin NE, van Oppen M, Willis BL, Mieog JC, Negri AP. Juvenile corals can acquire more carbon from high-performance algal symbionts. Coral Reefs. 2009;28:405-14.

26. Cunning R, Gillette P, Capo T, Galvez K, Baker AC. Growth tradeoffs associated with thermotolerant symbionts in the coral Pocillopora damicornis are lost in warmer oceans. Coral Reefs. 2015;34:155-60.

27. Jones A, Berkelmans R. Potential costs of acclimatization to a warmer climate: growth of a reef coral with heat tolerant vs. sensitive symbiont types. PLoS One. 2010;5:e10437.

28. Jones AM, Berkelmans R. Tradeoffs to thermal acclimation: Energetics and reproduction of a reef coral with heat tolerant Symbiodinium type-D. J Mar Biol. 2011;2011:1-12.

29. Pettay DT, Wham DC, Smith RT, Iglesias-Prieto R, LaJeunesse TC. Microbial invasion of the Caribbean by an Indo-Pacific coral zooxanthella. Proc Natl Acad Sci USA. 2015;112:7513-8.

30. Leal MC, Hoadley K, Pettay DT, Grajales A, Calado R, Warner ME. Symbiont type influences trophic plasticity of a model cnidarian-dinoflagellate symbiosis. J Exp Biol. 2015;218: $858-63$.

31. Matthews JL, Oakley CA, Lutz A, Hillyer KE, Roessner U, Grossman AR, et al. Partner switching and metabolic flux in a model cnidarian-dinoflagellate symbiosis. Proc R Soc Lond B. 2018;285:20182336.

32. Grottoli AG, Rodrigues LJ, Palardy JE. Heterotrophic plasticity and resilience in bleached corals. Nature. 2006;440:1186-9.

33. Wall CB, Ritson-Williams R, Popp BN, Gates RD. Spatial variation in the biochemical and isotopic composition of corals 
during bleaching and recovery. Limnol Oceanogr. 2019; 64:2011-28.

34. Anthony KRN. Enhanced energy status of corals on coastal, high-turbidity reefs. Mar Ecol Prog Ser. 2006;319:111-6.

35. Cooper TF, Ulstrup KE, Dandan SS, Heyward AJ, Kühl M, Muirhead A, et al. Niche specialization of reef-building corals in the mesophotic zone: metabolic trade-offs between divergent Symbiodinium types. Proc Biol Sci. 2011;278:1840-50.

36. Innis T, Cunning R, Ritson-Williams R, Wall CB, Gates RD. Coral color and depth drive symbiosis ecology of Montipora capitata in Kāne'ohe Bay, O'ahu, Hawai'i. Coral Reefs. 2018;37:423-30.

37. Sampayo EM, Franceschinis L, Hoegh-Guldberg O, Dove S. Niche partitioning of closely related symbiotic dinoflagellates. Mol Ecol. 2007;16:3721-33.

38. Cooper TF, Lai M, Ulstrup KE, Saunders SM, Flematti GR, Radford B, et al. Symbiodinium genotypic and environmental controls on lipids in reef building corals. PLoS One. 2011a;6: e20434.

39. Oliver TA, Palumbi SR. Do fluctuating temperature environments elevate coral thermal tolerance? Coral Reefs. 2011;30:429-40.

40. Jones AM, Berkelmans R, van Oppen MJH, Mieog JC, Sinclair W. A community change in the algal endosymbionts of a scleractinian coral following a natural bleaching event: field evidence of acclimatization. Proc Biol Sci. 2008;275:1359-65.

41. Lewis C, Neely K, Rodriguez-Lanetty M. Recurring episodes of thermal stress shift the balance from a dominant host-specialist to a background host-generalist zooxanthella in the threatened pillar coral, Dendrogyra cylindrus. Front Mar Sci. 2019;6:5.

42. Hoogenboom MO, Connolly SR, Anthony KRN. Effects of photoacclimation on the light niche of corals: a process-based approach. Mar Biol. 2009;156:2493-503.

43. Cooper TF, Berkelmans R, Ulstrup KE, Weeks S, Radford B, Jones AM, et al. Environmental factors controlling the distribution of Symbiodinium harboured by the coral Acropora millepora on the Great Barrier Reef. PLoS One. 2011b;6:e25536.

44. Anthony KRN. Coral suspension feeding on fine particulate matter. J Exp Mar Bio Ecol. 1999;232:85-106.

45. Muscatine L, Porter JW, Kaplan IR. Resource partitioning by reef corals as determined from stable isotope composition: I. $\delta^{13} \mathrm{C}$ of zooxanthellae and animal tissue vs depth. Mar Biol. 1989;100:185-93.

46. Rodrigues LJ, Grottoli AG. Calcification rate and the stable carbon, oxygen, and nitrogen isotopes in the skeleton, host tissue, and zooxanthellae of bleached and recovering Hawaiian corals. Geochim Cosmochim Acta. 2006;70:2781-9.

47. Fox MD, Williams GJ, Johnson MD, Radice VZ, Zgliczynski BJ, Kelly ELA, et al. Gradients in primary production predict trophic strategies of mixotrophic corals across spatial scales. Curr Biol. 2018;28:3355-63.

48. Alamaru A, Loya Y, Brokovich E, Yam R, Shemesh A. Carbon and nitrogen utilization in two species of Red Sea corals along a depth gradient: Insights from stable isotope analysis of total organic material and lipids. Geochim Cosmochim Acta. 2009; 73:5333-42.

49. Einbinder S, Mass T, Brokovich E, Dubinsky Z, Erez J, Tchernov D. Changes in morphology and diet of the coral Stylophora pistillata along a depth gradient. Marine ecology progress series Oldendorf. 2009;381:167-74.

50. Wham DC, Ning G, LaJeunesse TC. Symbiodinium glynnii $s p$. nov., a species of stress-tolerant symbiotic dinoflagellates from pocilloporid and montiporid corals in the Pacific Ocean. Phycologia. 2017;56:396-409.

51. Cunning R, Ritson-Williams R, Gates RD. Patterns of bleaching and recovery of Montipora capitata in Kāne'ohe Bay, Hawai' $i$, USA. Mar Ecol Prog Ser. 2016;551:131-9.
52. Stat M, Yost DM, Gates RD. Geographic structure and host specificity shape the community composition of symbiotic dinoflagellates in corals from the Northwestern Hawaiian Islands. Coral Reefs. 2015;34:1075-86.

53. Dana JD. Zoophytes. United States Exploring Expedition during the years 1838-1842. Philadelphia: Lea and Blanchard; 1846-1849.

54. Smith SV, Kimmerer WJ, Laws EA, Brock RE, Walsh TW. Kaneohe Bay sewage diversion experiment: perspectives on ecosystem responses to nutritional perturbation. Pac Sci. 1981;35:279-395.

55. PacIOOS. 2018. Pacific Island Ocean Observing System. http://www.pacioos.hawaii.edu/weather/obs-mokuoloe/.

56. Jeffrey SW, Humphrey GF. New spectrophotometric equations for determining chlorophylls a, b, c1 and c2 in higher plants, algae and natural phytoplankton. Biochem Physiol Pflanz. 1975;167:191-4.

57. Stimson J, Kinzie RA. The temporal pattern and rate of release of zooxanthellae from the reef coral Pocillopora damicornis (Linnaeus) under nitrogen-enrichment and control conditions. J Exp Mar Bio Ecol. 1991;153:63-74.

58. Wall CB, Ricci CA, Foulds GE, Mydlarz LD, Gates RD, Putnam HM. The effects of environmental history and thermal stress on coral physiology and immunity. Mar Biol. 2018;165:56.

59. Schlacher TA, Connolly RM. Effects of acid treatment on carbon and nitrogen stable isotope ratios in ecological samples: a review and synthesis. Methods Ecol Evol. 2014;5:541-50

60. Grottoli AG, Rodrigues LJ, Matthews KA, Palardy JE, Gibb OT. Pre-treatment effects on coral skeletal $\delta^{13} \mathrm{C}$ and $\delta^{18} \mathrm{O}$. Chem Geol. 2005;221:225-42.

61. Maier C, Weinbauer MG, Pätzold J. Stable isotopes reveal limitations in $\mathrm{C}$ and $\mathrm{N}$ assimilation in the Caribbean reef corals Madracis auretenra, M. carmabi and M. formosa. Mar Ecol Prog Ser. 2010;412:103-12.

62. Reynaud S, Martinez P, Houlbrèque F, Billy I, Allemand D, Ferrier-Pagès $\mathrm{C}$. Effect of light and feeding on the nitrogen isotopic composition of a zooxanthellate coral: role of nitrogen recycling. Mar Ecol Prog Ser. 2009;392:103-10.

63. Schoepf V, Levas SJ, Rodrigues LJ, McBride MO, Aschaffenburg MD, Matsui Y, et al. Kinetic and metabolic isotope effects in coral skeletal carbon isotopes: A re-evaluation using experimental coral bleaching as a case study. Geochim Cosmochim Acta. 2014;146:164-78.

64. Cunning R, Baker AC. Excess algal symbionts increase the susceptibility of reef corals to bleaching. Nat Clim Chang. 2013;3:259-62.

65. Akaike H. A Bayesian analysis of the minimum AIC procedure. Ann Inst Stat Math. 1978;30:9-14.

66. Oksanen J, Blanchet FG, Friendly M, Kindt R, Legendre P, McGlinn D, et al. 2019 vegan: Community Ecology Package. R package; version2.5-5.

67. Bates D, Mäechler M, Bolker BM, Walker SC. Fitting linear mixed-effects models using lme4. J Stat Softw. 2015;67:1-48.

68. Lenth, R. 2019 Emmeans: Estimated marginal means, aka leastsquares means. R package; version 1.3.3

69. Fox J, Weisberg S. An $\{\mathrm{R}\}$ Companion to Applied Regression. 2nd edn. Thousand Oaks CA: Sage; 2011.

70. Kuznetsova A, Brockhoff PB, Christensen RHB. lmerTest package: Tests in linear mixed effects models. J Stat Softw. 2017;82:1-26.

71. R Core Team. R: A language and environment for statistical computing. Vienna, Austria: R foundation for statistical computing; 2018.

72. Wall, C. cbwall/Coral-isotopes-across-space-and-time: Symbiont communities shape coral physiology and nutrition (Version v. publ). Zenodo. 2019. https://doi.org/10.5281/zenodo.3583424.

73. Mass T, Einbinder S, Brokovich E, Shashar N, Vago R, Erez J, et al. Photoacclimation of Stylophora pistillata to light extremes: 
metabolism and calcification. Mar Ecol Prog Ser. 2007; 334:93-102.

74. Frade PR, Englebert N, Faria J, Visser PM, Bak RPM. Distribution and photobiology of Symbiodinium types in different light environments for three colour morphs of the coral Madracis pharensis: is there more to it than total irradiance? Coral Reefs. 2008a;27:913-25.

75. Frade PR, De Jongh F, Vermeulen F, van Bleijswijk J, Bak RPM. Variation in symbiont distribution between closely related coral species over large depth ranges. Mol Ecol. 2008b; 17:691-703.

76. Storlazzi CD, Norris BK, Rosenberger KJ. The influence of grain size, grain color, and suspended-sediment concentration on light attenuation: Why fine-grained terrestrial sediment is bad for coral reef ecosystems. Coral Reefs. 2015;34:967-75.

77. Stat M, Gates RD. Clade D Symbiodinium in Scleractinian Corals: A 'Nugget' of Hope, a Selfish Opportunist, an Ominous Sign, or All of the Above? J Mar Sci. 2011;2011:1-9.

78. LaJeunesse TC, Thornhill DJ, Cox EF, Stanton FG, Fitt WK, Schmidt GW. High diversity and host specificity observed among symbiotic dinoflagellates in reef coral communities from Hawaii. Coral Reefs. 2004;23:596-603.

79. Jury CP, Toonen RJ. Adaptive responses and local stressor mitigation drive coral resilience in warmer, more acidic oceans. Proc Biol Sci. 2019;286:20190614.

80. Mass T, Kline DI, Roopin M, Veal CJ, Cohen S, Iluz D, et al. The spectral quality of light is a key driver of photosynthesis and photoadaptation in Stylophora pistillata colonies from different depths in the Red Sea. J Exp Biol. 2010;213:4084-91.

81. Swart PK, Saied A, Lamb K. Temporal and spatial variation in the $\delta^{15} \mathrm{~N}$ and $\delta^{13} \mathrm{C}$ of coral tissue and zooxanthellae in Montastraea faveolata collected from the Florida reef tract. Limnol Oceanogr. 2005;50:1049-58.

82. Cunning R, Baker AC. Not just who, but how many: the importance of partner abundance in reef coral symbioses. Front Microbiol. 2014;5:400.

83. DiPerna S, Hoogenboom M, Noonan S, Fabricius K. Effects of variability in daily light integrals on the photophysiology of the corals Pachyseris speciosa and Acropora millepora. PLoS One. 2018;13:e0203882.

84. Smith EG, D'Angelo C, Sharon Y, Tchernov D, Wiedenmann J. Acclimatization of symbiotic corals to mesophotic light environments through wavelength transformation by fluorescent protein pigments. Proc Biol Sci. 2017;284:20170320.

85. Kaniewska P, Magnusson SH, Anthony KRN, Reef R, Kühl M, Hoegh-Guldberg O. Importance of macro- versus microstructure in modulating light levels inside coral colonies. J Phycol. 2011;47:846-60.

86. Bayliss SLJ, Scott ZR, Coffroth MA, terHorst CP. Genetic variation in Breviolum antillogorgium, a coral reef symbiont, in response to temperature and nutrients. Ecol Evol. 2019; 9:2803-13.

87. Cui G, Liew YJ, Li Y, Kharbatia N, Zahran NI, Emwas A-H, et al. Host-dependent nitrogen recycling as a mechanism of symbiont control in Aiptasia. PLoS Genet. 2019;15(6): e1008189.

88. Sproles AE, Oakley CA, Matthews JL, Peng L, Owen JG, Grossman AR, et al. Proteomics quantifies protein expression changes in a model cnidarian colonised by a thermally tolerant but suboptimal symbiont. ISME J. 2019;13:2334-45.

89. Farquhar GD, Ehleringer JR, Hubick KT. Carbon isotope discrimination and photosynthesis. Annu Rev Plant Physiol Plant Mol Biol. 1989;40:503-37.

90. Loram JE, Trapido-Rosenthal HG, Douglas AE. Functional significance of genetically different symbiotic algae Symbiodinium in a coral reef symbiosis. Mol Ecol. 2007;16:4849-57.

91. Sogin EM, Putnam HM, Nelson CE, Anderson P, Gates RD. Correspondence of coral holobiont metabolome with symbiotic bacteria, archaea and Symbiodinium communities. Environ Microbiol Rep. 2017;9:310-5.

92. Hayes JM. Fractionation of carbon and hydrogen isotopes in biosynthetic processes. Rev Miner Geochem. 2001;43:225-77.

93. Tolosa I, Treignier C, Grover R, Ferrier-Pagès C. Impact of feeding and short-term temperature stress on the content and isotopic signature of fatty acids, sterols, and alcohols in the scleractinian coral Turbinaria reniformis. Coral Reefs. 2011;30:763.

94. Maier C, Pätzold J, Bak RPM. The skeletal isotopic composition as an indicator of ecological and physiological plasticity in the coral genus Madracis. Coral Reefs. 2003;22:370-80.

95. Grottoli AG, Wellington GM. Effect of light and zooplankton on skeletal $\delta^{13} \mathrm{C}$ values in the eastern Pacific corals Pavona clavus and Pavona gigantea. Coral Reefs. 1999;18:29-41.

96. Muscatine L, Kaplan IR. Resource partitioning by reef corals as determined from stable isotope composition II. $\delta^{15} \mathrm{~N}$ of zooxanthellae and animal tissue versus depth. Pac Sci. 1994; 48:304-12.

97. Fox MD, Elliott Smith EA, Smith JE, Newsome SD. Trophic plasticity in a common reef-building coral: Insights from $\delta^{13} \mathrm{C}$ analysis of essential amino acids. Funct Ecol. 2019;148:431.

98. Nahon S, Richoux NB, Kolasinski J, Desmalades M, Ferrier Pages C, Lecellier G, et al. Spatial and temporal variations in stable carbon $\left(\delta^{13} \mathrm{C}\right)$ and nitrogen $\left(\delta^{15} \mathrm{~N}\right)$ isotopic composition of symbiotic scleractinian corals. PLoS One. 2013;8:e81247.

99. Palardy JE, Grottoli AG, Matthews KA. Effects of upwelling, depth, morphology and polyp size on feeding in three species of Panamanian corals. Mar Ecol Prog Ser. 2005;300:79-89.

100. Anthony KR, Fabricius KE. Shifting roles of heterotrophy and autotrophy in coral energetics under varying turbidity. J Exp Mar Bio Ecol. 2000;252:221-53. 